\title{
Financial Sector Reforms and Stochastic Policy Simulations: A Flow of Funds Model for India*
}

\author{
Tomoe Moore, Coventry Business School, Coventry University \\ Christopher J. Green, Department of Economics, Loughborough University \\ Victor Murinde, School of Accounting and Finance, University of Birmingham
}

\begin{abstract}
We apply stochastic simulation methods to a system-wide flow of funds model for India for 1951-94. We address two issues; first, the impact of financial reforms on interest rates and loanable funds, and second, the robustness of policy where there is uncertainty about the true model. We find considerable variation in policy risk depending on the policy instrument and the policy regime. Interest rate risks are greater in the controlled regime; quantity risks are greater in the decontrolled regime. Outcomes also depend on controls on intermediaries: more heavily controlled banks respond differently from other less heavily controlled financial intermediaries.
\end{abstract}

Keywords: Stochastic Simulation; Policy analysis; Financial Liberalisation; Flow of loanable funds; India.

JEL Classification: E4, E5, G1, O16

\section{Correspondence to:}

Tomoe Moore, Coventry Business School, Coventry University, Coventry, CV1 5FB, United Kingdom, Tel: +44 (0)24 7688 7414, E-mail: T. Moore@ coventry.ac.uk

* The research underlying this paper forms part of 'Finance and Development Research Programme' funded by the Department for International Development (DFID). The interpretations and conclusions expressed in this paper are entirely our own and should not be attributed in any manner to DFID. We thank Kunal Sen for helpful comments on many aspects of this work. 


\section{Introduction}

One of the principal concerns in financial policy in developing countries is this: how reliably certain are the putative effects of a financial reform programme? It is generally accepted that financial repression imposes possibly substantial costs on an economy, and that it is desirable to eliminate these (Fry, 1997). However, there is considerable uncertainty about the appropriate speed and extent of reform. Asymmetric information and market failure are endemic in credit markets, even in the industrial countries, and there is a risk that liberalization in developing countries will bring new market failures or exacerbate existing ones, so that many of the gains from reform are reversed or lost altogether (Gibson and Tsakalotos, 1994; Stiglitz, 1998, Caprio et al., 2000). In general, the risks associated with liberalization appear to be more serious the less interest-elastic are financial flows in the reforming economy (Ogaki et al. 1996).

In this paper we adopt a novel approach to the analysis of financial reforms using as exemplar selected aspects of the reform process in India in the late 1980s and early 1990s. Our approach involves three key methodological contributions which, we believe, enhance our analysis and understanding of financial reform. First, we use as framework a disaggregated empirically-estimated flow of funds model. This enables us to provide a rigorous account of changes in financial flows and interest rates during a policy reform. In a system-wide flow of funds model, formed by combining the portfolio behaviour of individual sectors, interest rates and financial flows emerge endogenously as a result of the interactions between different sectors and their demands and supplies of assets and liabilities. The flow of funds approach also has the advantage of being relatively eclectic in that it can accommodate a wide range of special cases, and it is particularly useful in the context of a developing economy (Green et al. 2002; Green and Murinde, 2003). Industrial economies benefit from a vast range of deep and liquid markets whose prices provide much of the information upon which policy is based. In developing economies, where markets are more fragmented, and securities markets are often thin and 
illiquid, prices provide much less useful information. Therefore, information about quantities, such as the flow of funds, takes on a more important role.

Our second key contribution is that we use a structured framework to estimate the parameters of the model. Specifically, we use the almost ideal demand system (AIDS) of Deaton and Muellbauer (1980). This enables us to use theoretical restrictions, such as symmetry, to cut down the size of the estimation and simulation problems and therefore to obtain more efficient estimates than is possible using a more ad hoc approach (Backus et al. 1980). This in turn enables us to construct stochastic simulations which are more firmly grounded in the empirically-estimated model.

As our third contribution, we use stochastic simulation techniques to evaluate the robustness of different financial policies. More robust policies are those which generally yield better outcomes in the face of policy risk. Brainard (1967) suggested a two-way classification of policy risk: unexpected changes in exogenous variables, and uncertainty about the multiplier effects of instrument changes. In linear economic models, unexpected changes in exogenous variables are transmitted linearly into the policy targets (Poole, 1970). However, if a policy change encounters an unexpectedly large or small multiplier, its effects are transmitted into policy targets in a complex and non-linear way, even if the underlying model is itself linear. Policies which are based on the expected values of multipliers may go badly wrong if, as is likely, the multipliers themselves are imprecisely estimated, and subject to a high degree of uncertainty. Estimates of key economic parameters in developing countries are indeed typically much less precise than in the industrial countries; hence multiplier uncertainty is a central policy risk for developing countries. Consequently, financial reform is likely to face considerable execution risk in practise because of uncertainty about the true structure of the economy.

In summary, we estimate an empirical flow of funds model and carry out simulations permitting stochastic variations in key policy multipliers, especially the crucial interest rate 
elasticities. Stochastic simulation enables us to examine the impact of uncertainty in policy implementation, and the robustness of policy in the presence of uncertainty. Furthermore, the simulations are empirically based on the standard deviations of the estimated parameters. Therefore, the estimated range of outcomes gives a clear picture of the policy risks a government may face in carrying out financial reforms, and we find substantial differences between the results of stochastic simulations and those of equivalent 'naïve' deterministic simulations.

The model is estimated and simulated for the period 1951-94 for India. We address two main issues in the analysis. The first concerns the allocation of loanable funds. In financially repressed economies, loanable funds frequently remain locked inside banks or the public sector by a captive market in credit allocation and public debt. We therefore investigate the contribution of financial reform towards mobilising loanable funds from banks and other financial institutions (OFIs) to the private sector for productive economic activities. The second issue concerns the response of lending rates to policy reform and the extent to which reforms necessarily lead to higher interest rates as is widely believed (McKinnon, 1973, Shaw, 1973).

Flow of funds analysis has rarely been used in developing countries, particularly because of limited or non-existent data. Exceptionally, in the case of India, there exists comprehensive, detailed and disaggregated annual flow of funds data which run from 1951 through $1994^{1}$. This data period means that the analysis cannot be brought fully up-to-date, although it does cover the pre-reform and immediate post-reform eras. However, this does not limit the overall value of the study because a crucial contribution of this paper is the manner in which it employs stochastic simulations on a complete model of financial sector portfolio behaviour. This enables us to conduct a more rigorous analysis of the robustness of policy responses during financial liberalisation than has heretofore been carried out in a developing economy. For example, Sen et al. (1996) studied a flow of funds model for India, but their 
study is confined to the household and banking sectors; it covers a shorter sample period; and it is limited to deterministic simulations. Murinde (1992) and Murinde and Rawara (1996) conducted stochastic policy simulations but using a small macroeconomic model instead of a flow of funds model.

The rest of the paper is structured as follows. In section 2, we present the flow of funds framework for India. The demand functions are discussed in section 3; these are the building blocks of the model. Section 4 deals with the methodology of stochastic simulation. Empirical results and policy discussion are set out in section 5. Some conclusions are in section 6.

\section{A theoretical flow of funds matrix for India}

The Indian financial sector has been characterised by administrative rigidities since independence, and the banking sector has been subject to a range of government-administered regulations and controls. These include a mandatory Cash Reserve Ratio (CRR) and a Statutory Liquidity Ratio (SLR), the latter providing a captive market for public sector debt ${ }^{2}$. From 1969 when 20 major commercial banks were nationalised, the government stipulated a group of priority sectors and directed banks to lend to these sectors. Bank deposit rates were subject to ceilings and there was little scope to compete for funds from the private sector. Persistent government budget deficits led to a significant rise in the volume of government debt during the eighties, and the Reserve Bank of India (RBI) automatically monetised that part of the deficit which was financed by the ad hoc issue of 91-day Treasury Bills. Major financial sector reforms were undertaken in the early 1990's. These included a reduction in the statutory maximum levels for reserve ratios, and gradual dismantling of the administered interest rate structure. Fiscal reforms included a requirement that the government should finance its deficit from the market at market-related rates rather than by automatic monetisation by the RBI (Sen and Vaidya, 1997). 
The framework for the model is set out in table 1. Each column indicates a sector and each row a set of financial instruments. Each cell shows the net acquisition or disposal of an instrument by the corresponding sector. Cell entries can be positive, negative or zero depending on whether the sector accumulates net assets (+) or net obligations (-) in the instrument in question. Cells marked with $(\cdot)$ are those which are to be explained by behavioural equations. There are five sectors and six instruments ${ }^{3}$. Allowing for several empty cells, this implies the estimation of 15 demand functions in the complete model.

\section{Table 1 about here}

Each financial market must be cleared, either by movements in prices or quantities, possibly accompanied by some direct rationing process. The market clearing conditions are that the net demands for and supplies of instruments in each row of the matrix must sum to zero. An $\mathrm{N}$-market flow of funds matrix provides $\mathrm{N}-1$ independent endogenous market-clearing variables, given that sectoral net worth is assumed to be exogenous (Backus et al. 1980, Green 1984). Currency has its nominal yield fixed at zero and this is assumed to be the Nth market. The remaining $(\mathrm{N}-1)$ market-clearing variables are determined as follows. Bank rate is a policy instrument, but it affects commercial banks' excess reserves ${ }^{4}$. Excess reserves are treated as demand-determined given bank rate, and are therefore a market-clearing variable. In the prereform era, deposit rates were controlled and banks could not bid for funds by changing interest rates. Following reform, banks may set their own deposit rates, but at any point in time, they still accept all deposits placed with them at the current rate. So, the quantity of deposits is a market-clearing variable in both pre- and post-reform periods. In the government debt market, prior to liberalisation, debt yields were controlled by the authorities. The flow of government debt was therefore determined by the asset choices of investors. Following liberalisation, 
government debt yields have been set more in line with market-related rates, and the debt yield can therefore be interpreted as a market-clearing variable. For simulation purposes, we analyse two regimes, one with government debt endogenous (R1), and one with debt yields endogenous (R2). In the markets for company securities and loans and advances the market clearing variables are assumed to be the relevant rates of return: on shares and on loans respectively ${ }^{5}$.

Using the national flow of funds accounts compiled by the RBI, we constructed the necessary time series of stocks and flows for the period 1951-52 through 1993-94 ${ }^{6}$. Using $31^{\text {st }}$ March 1951 as a benchmark, the subsequent stock data are constructed by incrementing successive annual flows.

\section{Estimation of behavioural equations}

A key practical problem with flow of funds models is that they can easily become too large to be solved easily. We circumvent this problem by using the AIDS model (Deaton and Muellbauer, 1980) to estimate the asset demands. This provides a rigorous characterization of the asset demands and enables the use of theoretical restrictions, such as symmetry to cut down the size of the estimation problem. Demand theory permits us to define the utility function directly in terms of assets, which may be more appropriate than the mean-variance approach, given that different assets do have different characteristics other than mean and variance. We assume that agents maximise a utility function, which depends on the expected real value of their financial assets: $u=u\left(a_{1, t+1}^{\tau}, a_{2, t+1}^{\tau}, \ldots, a_{n, t+1}^{\tau}\right)$, where $a_{i, t+1}^{\tau}=a_{i, t+1} / Z_{t+1}=$ real holdings of the $i$ th asset or liability at the end of period $t+1$ and $Z_{t}=$ goods price index. The budget constraint states that real assets sum to real wealth: $\sum_{i} a_{i t}^{\tau}=W_{t}^{\tau}=(W / Z)_{t}$, where $W_{i}^{\tau}=$ real wealth at the end of period $t$. The AIDS model is flexible, as it allows economically rational auxiliary variables, such as the CRR and SLR, which may influence the demand for a particular financial instrument, to be included as part of the agents' baseline or subsistence asset holdings without 
violating the axioms of rational choice in consumer demand theory. Following Barr and Cuthbertson (1991), the AIDS share equation $\left(S_{i}\right)$ is given by:

$$
S_{i}=a_{i t} / W_{t}=\alpha_{i}+\sum_{j} \gamma_{i j} \ln p_{j t}^{\tau}+\sum_{k} \theta_{i k} h_{k t}+\beta_{i} \ln \left(W^{\tau} / P^{* \tau}\right)_{t}
$$

here: $\left.\left.p_{i}^{\tau}=\llbracket 1+r_{i}\right)(1-g)\right]^{1} ; r_{i}=$ expected nominal return on asset $i$ from $t$ to $t+1 ; g=$ expected rate of goods price inflation from $t$ to $t+1, \ln P^{*_{\tau}}=\sum S_{i} \ln p_{i t}^{\tau}$; and $h_{k}=$ the auxiliary variables. Interest rates $\left(r_{i}\right)$ used to construct the AIDS prices $\left(p_{i}^{\tau}\right)$ are as follows: the inverse of the inflation rate for currency, Bank rate for excess reserves, the deposit rate for deposits, government debt yields for government debt, the return on shares ${ }^{7}$ for company securities, and the lending rate for loans. We include the CRR and SLR as conditional variables in the banks' asset demand functions, thus allowing for the possibility that baseline asset holdings vary with the size of these ratios. The aggregate income-wealth ratio, aggregate expenditure and the real exchange rate are also included as conditional variables to capture baseline holdings of financial assets, which are not determined by interest rates. During the estimation period, India experienced two major regime shifts: the nationalisation of major commercial banks and the introduction of priority sector lending requirements in 1969; and the initiation of liberalization in 1990. Chow forecast tests suggested that there were structural breaks at these dates, and two dummies were included in the equation system to model these breaks in a simple way.

Given the budget constraint $\left(\sum_{i}^{n} S_{i}=1\right)$ the AIDS system of equations for each sector was estimated by the seemingly unrelated regression (SUR) technique, which takes account of any contemporaneous correlation in the errors across equations. Given the relatively small number of annual observations (43), the empirical focus in the present paper is on the long-run relationships in each sector. Gains from financial reform are also expected to accrue particularly in the long-run. To gain efficiency, a general-to-specific methodology was adopted with 
homogeneity and symmetry implied by the axioms of rational choice in demand theory imposed across equations, and with zeroes imposed where the data or economic theory would permit. Overall, the estimated long-run models are quite satisfactory in terms of sign and statistical significance $^{8}$. The detailed results and diagnostic information can be found in Moore (2003), Moore et al. (2005) and Moore and Green (2005a and 2005b).

\section{Simulations}

\subsection{Methodology}

There is no single recognised approach to stochastic simulation experiments (Hall, 1986). We concentrate on the uncertainty embedded in the estimated values of the model parameters, and focus on random effects in the interest rate (or AIDS price) parameters in the estimated long-run models of banks and other financial institutions. It is the interest rate effects which are difficult to estimate with a high degree of precision but which are also the key determinants of the impact of policy changes in the financial sector. Likewise, financial institutions are the main conduit through which monetary policy flows to affect the economy as a whole. Therefore, if financial intermediaries' portfolio responses to interest rate changes are different from prior expectations (represented here by the estimated AIDS price elasticities of the model), this is likely to have a critical effect on the impact of policy, and the effectiveness of reform programmes.

The simulations were run from 1969-70 to 1993-94, covering the period after the nationalization of the major commercial banks in 1969. We specify the distribution of the AIDS price coefficients as follows: each coefficient is assumed to be normally distributed with mean given by the point estimate, and standard deviation given by the estimated standard errors. We then draw randomly from a normal distribution with these properties, and a similar drawing is done for each coefficient. We maintain the theoretical restrictions of homogeneity and symmetry in these drawings but we otherwise assume that the coefficients are independently 
distributed; that is, we do not explicitly take into account the covariances among coefficient estimates $^{9}$. The model is then simulated with the randomly-drawn values of the coefficients, and the whole process repeated 500 times. The simulations are summarized by calculating the means and standard deviations of the outcomes each period and then over the simulation period as a whole. Following Murinde (1992) and Murinde and Rawara (1996), we evaluate the impact of policy risk by comparing the stochastic simulation results with those of a deterministic simulation using the empirically-estimated coefficients. If policy effects are insensitive to the true structure of the model (i.e. there is no large deviation in results between stochastic and deterministic simulations), then the policy is robust. But if policy effects are sensitive (i.e. there is a large deviation), then the policy may not be robust.

The effects of policy on the $i$ 'th endogenous variable $\left(\delta_{i}\right)$ are calculated as the difference between the outcome in which a policy instrument is shocked and the outcome in the base run in which all exogenous variables are set at their historic levels.

$$
\delta_{i}=Y_{i}^{\text {simu }}-Y_{i}^{\text {base }}
$$

where: $\quad Y_{i}^{\text {base }}=$ time mean of simulated values of $Y_{i}$ using the historic exogenous variables;

$Y_{i}^{\text {simu }}=$ time mean of simulated values of $Y_{i}$ with a change in some exogenous variable.

The difference between the deterministic and the stochastic simulation is that in the former, the time means are calculated using the actual simulated values, whereas in the latter, the time means are calculated from each year's average of the outcomes of the 500 random drawings.

\subsection{Policy Experiments}

The following policies were simulated:

1. Cash Reserve Ratio (CRR) reduced by $2 \%$;

2. Bank Rate reduced by $2 \%^{10}$;

3. Statutory Liquidity Ratio (SLR) reduced by $2 \%$;

4. Deposit rate increased by $2 \%$. 
5. Government Debt Yields reduced by 2\%;

6. Open market purchase of government securities by $2 \%$ of the outstanding amount.

The CRR, bank rate and SLR are the key monetary instruments in India, and lowering the statutory level of all these was explicit in the financial reform programmes. It is commonly argued that interest rate ceilings in developing countries have been a principle source of financial repression, often associated with negative real deposit rates. In India, it was indeed the case that the actual mean real deposit rate in the simulation period was $-1.45 \%$. Therefore, in simulation 4 we increased the real deposit rate by $2 \%$ as a proxy for a de-regulation of deposit rates. Following liberalization, it was envisaged that open market operations would become the principal instrument of liquidity management in India, with new issues being sold through RBI auctions. In practise, although interest rates on government debt were increasingly marketdetermined in the post-reform period, the rules of the auctions effectively still allowed the RBI to set the rate (Hanson et al., 2000). Therefore, we carried out 2 simulations involving government debt. In simulation 5 we shocked the yield on government securities and in simulation 6 we performed a standard open market operation.

The effect of financial liberalisation is examined in two regimes: in the first (R1), yields on government debt are assumed to be controlled by the RBI, with the quantity of debt adjusting endogenously; in the second (R2), yields on government debt are de-controlled and the RBI is assumed to sell debt at market interest rates. S1 - S4 can be (and were) run in both regimes. However, S5 is run only under regime 1 and S6 only under regime 2. This makes 10 simulations in all, each of which were run as a stochastic and then as a deterministic simulation. There are twenty endogenous variables and twenty simulations, making a total of 400 solutions of possible interest. To address the key issue in this paper of policy robustness during financial reform, we concentrate on the impact of policy on just two variables: the intersectoral flows of loans and the bank lending rate. The former tells us about the contribution of monetary policy 
to mobilising loanable funds from financial institutions to the private sector. The second concerns the response of lending rates to policy changes and the extent to which reforms necessarily lead to higher interest rates.

\section{Empirical Results and Policy Implications}

Table 2 presents the simulated policy effect on lending rates. In general, the results are plausible, as policy changes which one would expect to be unambiguously expansionary $(1,2,5$, 6) do produce a fall in the lending rate in both regimes. There are also many interesting details as we now discuss.

\section{Table 2 about here}

India has made active use of variations in the CRR and the SLR in implementing its monetary policy. A change in a reserve ratio is usually a powerful policy instrument as it typically creates a substitution effect and a wealth effect which both work in the same direction. The substitution effect arises from the tax implications of a reserve ratio. If banks are constrained to hold a certain minimum proportion of their assets in cash or government debt which pay lower interest rates than do loans or company securities, it is equivalent to a tax levied on the rate on bank lending ${ }^{11}$. The wealth effect arises from the fact that a reserve ratio imposes a quantitative restriction on the size of a bank's loan portfolio. Thus, a reduction in the CRR reduces both the tax on the price of loans and the quantitative restriction on their amount, thus increasing the supply and tending to lower the rate on loans.

In our results, a reduction in the $\boldsymbol{C R R}$ does indeed affect the loan rate in the expected way in both the controlled and decontrolled regimes, although its effect is smaller in the controlled regime. However, Bank rate changes exert relatively little effect on the loan rate in the controlled regime, suggesting that changes in rates were moderated by the RBI's operations 
required to stabilize the government bond yield. This shows that the effects of interest rate changes may be nullified in a controlled regime. In contrast, a cut in the $\boldsymbol{S L R}$ is found to be a relatively risky policy as the loan rate falls in the deterministic simulation as might be expected, but it rises and substantially so, in the stochastic simulation. The direct effect of a decrease in the SLR is to reduce bank demand for government debt, increase bank demand for company securities, and reduce bank supply of loans. The latter tends to increase the loan rate. However, the indirect effects arising through the substitutability of assets and liabilities in other sectors may tend to reduce the loan rate. The overall effect depends on the interest elasticities of demand for assets and liabilities in all sectors, and the risks that these are imprecisely estimated. The stochastic simulation results show that the direct effects may outweigh the indirect effects and lead to an overall increase in the loan rate.

A rise in the deposit rate is also found to be a relatively risky policy, although less so than the change in the SLR. The deterministic simulation predicts a rise in the loan rate, but the stochastic simulation predicts a fall. This result highlights the important point that it is oversimplistic to expect that the effects of deregulation will be unambiguously to move all interest rates in the same direction. The effects of a rise in the deposit rate depend on the interest elasticities of demand for assets and liabilities in all sectors. This suggests that a "big-bang" deregulation of deposit rates may be inappropriate, especially for India where competition among banks was limited not just by RBI controls but also because the banking system was relatively cartelised. It is generally agreed that competitive banking is necessary, though not sufficient, for a decontrolled financial system to function effectively (Fry 1995).

In the controlled regime, the most effective way to influence the cost of debt capital (the loan rate) is to change the regulated rate on government debt. This is because debt and loans are close substitutes in bank and OFIs' balance sheets, so that a change in one rate is transmitted strongly to the other. 
An important general feature of these results is that the standard errors of the stochastic simulations are generally lower in the decontrolled regime (R2) than they are in the controlled regime $(\mathrm{R} 1)^{12}$. This is a very interesting finding as it provides support for the argument that a properly-functioning market works more predictably than one which is affected by controls. One might expect that in a controlled regime, interest rate changes would be smaller in response to policy and other external shocks, than in the decontrolled regime, because of the buffer provided by RBI transactions in government debt required to maintain the controlled government debt yield. This is after all one of the purposes of the controls. We do indeed see that the mean effects in the stochastic simulations are lower in the controlled regime as we would expect. However, the relative standard errors (RSE) are higher in the controlled regime (R1) than in the decontrolled regime (R2). This implies that policy risks for interest rate effects are higher in the controlled regime. In other words, the effect of a shock is less predictable in the controlled regime and therefore policy-making is more prone to error. Potentially, this provides a powerful argument for decontrol: even if interest rate movements are greater in the decontrolled regime, they are more certain in size and direction.

\section{Table 3 about here}

Table 3 shows the policy effects on the amount of loans outstanding as between lenders (banks and OFIs) and borrowers (households and PCBs). A positive (negative) sign implies increased (reduced) lending by banks and OFIs, and increased (reduced) borrowing by households and PCBs.

These results are consistent with and help clarify the results for the loan rate. The $\boldsymbol{C R R}$ reduction increases the supply of bank loans as it simultaneously reduces the reserve ratio tax rate on loans and frees up bank portfolios to increase lending. Therefore, as the loan rate falls 
(table 2), the amount of loans outstanding to the private sector increases; and OFI lending increases as well as that by banks. As part of a financial reform, one would expect a gradual lowering of the CRR to reduce the tax on loan rates and relieve bank portfolio constraints (McKinnon, 1988). As our results suggest, such a policy would be consistent with increased availability of loanable funds for the private sector at lower cost.

Correspondingly, changes in Bank rate have a negligible impact on the flow of loans as they do on the lending rate. The ineffectiveness of bank rate is due in large part to the fact that the main substitute for excess reserves in bank portfolios is government debt. Thus, the main direct effect of a cut in bank rate is to increase bank demand for government securities, a cushion of which is required by the SLR regime. This conclusion again reinforces the point that the effectiveness of policy will depend in large part on all the interest elasticities of demand in the different sectors of the model. Bank rate is traditionally thought of as a basic tool of policy but, in a regime where cash and liquidity ratios are high and actively used, changes in Bank rate only have a substitution effect on bank portfolios, and if this is concentrated on reserves and government debt, the effect in the loan market is small. However, changes in the reserve ratios themselves are likely to be much more effective (as we find) because they involve both a substitution effect and a reinforcing wealth effect.

A main purpose of the SLR is to provide a captive market for government securities, and this would suggest that a reduction in the SLR would be expected to increase private sector lending. In fact, the effect of the SLR reduction in our model depends on the simulation (stochastic or deterministic) and on the policy regime (R1 or R2). In the controlled regime, lending falls even though the loan rate rises (in the stochastic simulations). This can be explained by an increased demand for company securities by financial institutions and reduced demand for loans by the private sector. In the decontrolled regime, lending falls in the deterministic simulation, but in the stochastic simulation total lending increases, although this is 
attributable to OFI activity, as bank lending falls. These differences in sign are determined by the whole structure of interest rate elasticities and their standard errors. The differences between the deterministic and stochastic simulation results confirm that SLR changes are a relatively risky policy, especially as the SLR change exerts a relatively large impact on lending. The riskiness of an SLR change in respect of its impact on lending and interest rates may in part be due to its complexity. Under the scheme, banks are obliged to subscribe not only to government securities, but also to government-approved company securities. Therefore a cut in the SLR may lead to unexpected substitutions between government and private debt and through this route may either decrease or increase the amount of loanable funds for the private sector. Reductions in the SLR may involve further policy risks if other measures are implemented simultaneously as part of a general financial reform. If for example, rates on government debt are decontrolled, they will tend to rise relative to other rates and this will increase the attractiveness of government debt for banks as low-risk, high-yield assets irrespective of changes in the SLR (Green et al. 2002)

The effects of changing any of the deposit rate, government debt or debt interest rates (4-6) also depend both on the simulation and on the policy regime. In the controlled regime, lending rises as the loan rate falls, following either a rise in the deposit rate or a cut in the government debt yield. In the decontrolled regime, the deterministic simulations suggests that lending rises following a rise in the deposit rate or an open market purchase, but in the stochastic simulations it decreases (although by a relatively small percentage for the open market purchase), and this is again attributable particularly to OFI activity.

For the loan rate, the predominant policy risks are in the controlled regime. The reverse is true for the amount of loans: in general, the policy risks are greater in the decontrolled regime, particularly for the open market purchase of government debt. The main difference between controlled and decontrolled markets is that, in the latter greater reliance is placed on the 
price (interest rate) mechanism and less on quantities. However, as we noted at the outset, where there are substantial market imperfections and asymmetric information, quantities are likely to be as important as prices. Therefore it is not possible to state that our evidence provides unambiguous support for more or less decontrol. Clearly though it does underscore our central message that, where information is imperfect, policy-making is risky and it is typically more risky the less perfect is the available information. It may prove to be the case, in determining the appropriate degree of decontrol and the appropriate instrument set, that the authorities do have to choose between greater risks in quantity outcomes or greater risks in price outcomes. This after all is the central message in the pioneering contribution to this issue of Poole (1970).

A final important point is apparent from the results on loans outstanding, and that concerns the role of banks and OFIs in the context of the two policy regimes. First, in general, OFI lending responds more to the simulated policy changes than does bank lending. In terms of the model, this difference can be explained by the generally higher estimated interest elasticities among the OFIs' asset demands. However, this result is entirely consistent with their being subject to fewer controls than the commercial banks, particularly the general absence of direct controls on their use of funds such as the CRR and SLR to which the banks are subject. The second manifestation of the greater freedom enjoyed by OFIs is that, in many cases, bank lending and OFI lending have opposite signs. These properties of the estimates and simulations provide a clear reminder of the basic point originally made by Tobin and Brainard (1963) that financial controls which fall on one group of intermediaries (in this case banks) leaving others uncontrolled (in this case OFIs) will be less effective than if all intermediaries are subject to a common set of regulations. Furthermore, depending on the pattern of asset substitutability in all the different sectors of the economy, it is possible that standard policy measures may have 
unexpected and possibly undesirable effects because of the interactions between the portfolio choices of the controlled and the uncontrolled intermediaries.

\section{Concluding remarks}

In this paper we reported on a flow of funds model for India concentrating on the results of stochastic simulations aimed at identifying possible risks involved in the implementation of policies often associated with financial reform packages: especially reductions in reserve ratios and freeing up of interest rates. We offer three main contributions to the financial reform debate: a fully specified disaggregated flow of funds model; a systematic estimation procedure based on the AIDS model; and stochastic simulations which involve shocking the estimated policy multipliers of the model, concentrating on the crucial interest elasticities, rather than the more simplistic procedure of shocking the residuals. We concentrate on the effects of policy on the loan rate and the flow of lending to the private sector. Of course, we recognise that there are some important limitations to the analysis. First, for tractability the model concentrates on financial variables, taking the real side of the economy as given. Second, data limitations mean that the estimated model terminates in 1994 during the reform period. It is therefore not possible to provide a comprehensive analysis of all the reforms that did in fact take place in the 1990s. Finally, the model is specific to India and policy effects may be different in different economies. However, none of these limitations should vitiate the main findings of the paper.

The main results for specific policy instruments are as follows. First, a reduction in the CRR does have the expected theoretical impact, increasing lending and reducing the loan rate. Second, other relatively standard policies have less impact or pose certain risks. Thus, bank rate changes appear relatively ineffective in changing interest rates or loans outstanding. Changes in

the banks' deposit rate or the SLR is more effective, but varies in direction (sign of the multiplier) with the type of simulation (deterministic or stochastic) and the policy regime 
(controlled or decontrolled government debt yields), suggesting that potentially important risks are associated with the use of these instruments.

There are also two more general results. First, price (interest rate) risk is greater in the controlled regime, whereas quantity risk is greater in the decontrolled regime. This is not necessarily a surprising result. However, it is important to emphasize that it does not follow directly from the design of the model, but is an empirical outcome of the stochastic simulations. It emphasizes that all policy changes involve certain risks, and good policy, especially major reforms, need to be designed with these risks in mind. The second result is that in many instances, the equilibrium responses to policy changes are different in direction as between banks and OFIs. We would again emphasize that this is not a consequence of perverse coefficient estimates but an endogenous result of generally higher point estimates of interest elasticities for OFIs and different system-wide parameter risks in the two sectors. The differing behaviour of banks and OFIs is almost certainly attributable to the fact that the latter have been subject to fewer controls than banks. Our results emphasize that any liberalization or other policy programme must take account of the differing degrees of control of the main financial institutions through which policy is channelled.

Overall, our results provide strong support for the value of a system-wide approach to understanding financial policy and for the hypothesis that policy effects in the presence of uncertainty are quantitatively and qualitatively different from those in a world of certainty. Policy-makers need to take this uncertainty into account and this implies a more cautious approach to policy-making. 


\section{References}

Artis, M.J. Ashurst, P., Green, C.J., Miller M.H. and Walker I. 1978. "Competition and Credit Control., Evidence to the Committee to Review the Functions of Financial Institutions (The Wilson Committee), August.

Backus, D., Brainard, W.C, Smith, G. and Tobin, J. 1980. "A Model of US Financial and NonFinancial Economic Behaviour.” Journal of Money, Credit and Banking 12: 259-293.

Barr, D.G. and Cuthbertson, K. 1991. "Neo-classical Consumer Demand Theory and the Demand for Money.” Economic Journal, 102: 855-876.

Brainard, W.C. 1967. "Uncertainty and the Effectiveness of Policy." American Economic Review 57: May, 411-425.

Caprio, G., Hanson, J.A. and Honohan, P. 2000. "Introduction and Overview: The Case for Liberalization and Some Drawbacks." in Caprio, G. Honohan, P. and Stiglitz, J. (eds.), Financial Liberalisation, Cambridge, Cambridge University Press.

Deaton, A.S. and Muellbauer, J. 1980. "An almost Ideal Demand System", American Economic Review 70: 312-326.

Fry, M.J. 1995. Money, Interest and Banking in Economic Development $2^{\text {nd }}$ edition: Baltimore, The Johns Hopkins University Press.

Fry, M.J. 1997. “In Favour of Financial Liberalization.” Economic Journal 107: May, 754-770.

Gibson, H.D. and Tsakalotos, E. 1994. "The Scope and Limits of Financial Liberalization in Developing Countries: A Critical Survey." Journal of Development Studies 30: 578-628.

Green, C.J. 1984. "Preliminary Results from A Five-Sector Flow of Funds Model of the United Kingdom, 1972-77.” Economic Modelling 1: July, 304-326.

Green, C.J. and Kiernan, E. 1989. "Multicollinearity and Measurement Error in Econometric Financial Modelling." Manchester School 55: December, 357-369.

Green, C.J. and Murinde, V. 2003. "Flow of Funds: Implications for Research on Financial Sector Development and the Real Economy." Journal of International Development 15: 10151036.

Green, C.J., Murinde, V. and Moore, T. 2002. The Flow of Funds' Finance and Development Briefing Papers, June, Finance and Development, Department for International Development.

Hall, S.G. 1986. "The Application of Stochastic Simulation Techniques to the National Institute's Model 7.” The Manchester School 54: 180-201.

Hanson, J.A. 2000. "How Interest Rates Changed under Liberalization: A Statistical review." in Caprio, G. Honohan, P. and Stiglitz, J. (eds.) Financial Liberalisation, Cambridge: Cambridge University Press. 
McKinnon, R.I. 1973. Money and Capital in Economic Development: Washington, DC, The Brookings Institution.

McKinnon, R.I. 1988. "Financial Liberalization in Retrospect: Interest Rate Policies in LDCs." in Ranis, G., Schultz, T.P. (eds.), The State of Development Economics: Progress and Perspectives. Basil Blackwell.

Moore, T. 2003. Modelling a Flow of Funds and Policy Simulation Experiments for India. Unpublished Ph.D. thesis, Loughborough University.

Moore, T., Green, C.J. and Murinde, V. 2005. "A Flow of Funds Model for the Household Sector for India.” Journal of Development Studies 41: April, 676-703.

Moore, T. and Green, C.J. 2005a. "Financial Liberalization and Policy Simulation Experiments for India." International Journal of Economic Research. (forthcoming).

Moore, T. and Green, C.J. 2005b. Other Financial Institutions' Portfolio Behaviour and Policy Implications: A Study of India. International Economic Journal. (forthcoming).

Murinde, V. 1992. "Application of Stochastic Simulation and Policy Sensitivity Techniques to a Macroeconomic Model of Uganda." Applied Economics 24: 1-17.

Murinde, V. and Rarawa, D.H. 1996. "Modelling the Potency of Stabilization Policy for the Solomon Islands, 1978:1Q-1992:4Q.” Applied Economics 28: 309-319.

Ogaki, M., Ostry, J. and Reinhart, C.M. 1996. "Saving Behaviour in Low and Middle-Income Developing Countries: A Comparison.” IMF Staff Papers 43: March, 38-71.

Poole, W.M. 1970. "Optimal Choice of Monetary Policy Instruments in a Simple Stochastic Macro-Model." Quarterly Journal of Economics, 85: May, 197-216.

Sen, K., Roy, T., Krishnan, R. and Mundlay, A. 1996. "A Flow of Funds Model for India and Its Implications." Journal of Policy Modelling 18: 469-494.

Sen, K. and Vaidya, R. 1997. The Process of Financial Liberalization in India. New Delhi: Oxford University Press.

Shaw, E.S. 1973. Financial Deepening in Economic Development. New York: Oxford University Press.

Smith,G. 1981. "The systematic specification of a full prior covariance matrix for asset demand equations." Quarterly Journal of Economics 96: 317-339.

Stiglitz, J.E. 1998. "The Role of the State in Financial Markets." Proceedings of the World Bank Annual Conference on Development Economics: 19-52.

Tobin, J. and Brainard, W.C. 1963. "Financial Intermediaries and the Effectiveness of 'Monetary Controls'." American Economic Review Papers and Proceedings 53: May, 383-400. 
Table 1. India: theoretical flow of funds model

\begin{tabular}{|l|c|c|c|c|c|l|}
\hline & $\begin{array}{c}\text { Govern- } \\
\text { ment }\end{array}$ & Banks & $\begin{array}{c}\text { Other } \\
\text { Financial } \\
\text { Institutions } \\
\text { (OFIs) }\end{array}$ & $\begin{array}{c}\text { Private } \\
\text { Corporate } \\
\text { Business } \\
\text { (PCBs) }\end{array}$ & $\begin{array}{c}\text { House- } \\
\text { holds }\end{array}$ & $\begin{array}{c}\text { Market-clearing } \\
\text { Endogenous } \\
\text { Variables }\end{array}$ \\
\hline Currency & - & & & & $+(\cdot)$ & \\
\hline $\begin{array}{l}\text { Excess } \\
\text { Reserves }\end{array}$ & - & $+(\cdot)$ & & & & Excess reserves \\
\hline Deposits & $-(\cdot)$ & Deposits \\
\hline $\begin{array}{l}\text { Government } \\
\text { Debt }\end{array}$ & - & $+(\cdot)$ & $+(\cdot)$ & $+(\cdot)$ & $+(\cdot)$ & $\begin{array}{l}\text { Gov. debt (R1) or } \\
\text { Gov. debt yd.(R2) }\end{array}$ \\
\hline $\begin{array}{l}\text { Company } \\
\text { Securities }\end{array}$ & & $+(\cdot)$ & $-(\cdot)$ & $-(\cdot)$ & $+(\cdot)$ & Return on shares \\
\hline Loans & & $+(\cdot)$ & $+(\cdot)$ & $-(\cdot)$ & $-(\cdot)$ & Lending rate \\
\hline Net Worth & - & 0 & 0 & - & + & \\
\hline
\end{tabular}

$(\cdot)=$ behavioural equations.

Government debt includes government securities, government deposits, small savings.

Company Securities includes Paid-up capital and Unit Trust capital.

Loans include loans and advances, fixed deposits of PCB sector, bonds and debentures.

Empty cells are those with zero or negligible transactions; they are treated as exogenous.

Table 2 Simulated policy effects on bank lending rate

\begin{tabular}{|l|c|c|c|c|c|c|}
\hline & \multicolumn{3}{|c|}{$\begin{array}{c}\text { R1 } \\
\text { Gov't debt yields controlled }\end{array}$} & \multicolumn{3}{c|}{ R2 } \\
Gov't debt yields de-controlled \\
\hline & D (\%) & S (\%) & RSE & D (\%) & S (\%) & RSE \\
\hline 1. CRR reduced by 2\% & -0.46 & -1.02 & 0.51 & -1.69 & -3.80 & 0.07 \\
\hline 2. Bank rate reduced by 2\% & 0.00 & -0.01 & 6.89 & -0.24 & -0.43 & 0.11 \\
\hline 3. SLR reduced by 2\% & -0.48 & +1.35 & 1.52 & -0.06 & +3.98 & 0.31 \\
\hline 4. Deposit rate increased by 2\% & +0.53 & -0.60 & 1.73 & +0.13 & -1.91 & 0.31 \\
\hline 5. Gov.debt Yds reduced by 2\% & -1.05 & -1.90 & 0.31 & & & \\
\hline 6. OMO purchases 2\% & & & & -0.54 & -1.10 & 0.13 \\
\hline
\end{tabular}

$\mathrm{D}=$ Deterministic simulation, $\mathrm{S}=$ Stochastic simulation

$\mathrm{RSE}=$ Relative Standard Error defined as SE/mean, where SE $=\mathrm{SD} / \sqrt{500}$ and SD $=$ Standard Deviation of the stochastic simulation 
Table 3 Simulated policy effects on loans outstanding

\begin{tabular}{|c|c|c|c|c|c|c|}
\hline & \multicolumn{3}{|c|}{$\begin{array}{c}\text { R1 } \\
\text { Gov't debt yields controlled }\end{array}$} & \multicolumn{3}{|c|}{$\begin{array}{c}\mathrm{R} 2 \\
\text { Gov't debt yields de-controlled }\end{array}$} \\
\hline & D $(\%)$ & $\mathrm{S}(\%)$ & RSE & D (\%) & $\mathrm{S}(\%)$ & RSE \\
\hline \multicolumn{7}{|c|}{ 1. CRR reduced by $2 \%$} \\
\hline Banks & +3.51 & +3.05 & 0.30 & +3.16 & +6.73 & 0.10 \\
\hline OFI & +20.98 & +20.10 & 0.83 & +16.72 & +12.63 & 1.86 \\
\hline PCB (-) & +9.10 & +8.46 & 0.60 & +6.60 & +8.26 & 0.85 \\
\hline Household (-) & +6.87 & +6.34 & 0.53 & +6.42 & +6.44 & 0.76 \\
\hline \multicolumn{7}{|c|}{ 2. Bank rate reduced by $2 \%$} \\
\hline Bank & +0.01 & +0.02 & 6.04 & +0.16 & +0.59 & 0.33 \\
\hline OFIs & +0.18 & -0.14 & 15.95 & +4.55 & -4.15 & 1.36 \\
\hline PCB (-) & +0.06 & -0.03 & 21.47 & +1.47 & -0.98 & 1.69 \\
\hline Household (-) & +0.05 & -0.02 & 21.79 & +1.27 & -0.54 & 2.12 \\
\hline \multicolumn{7}{|c|}{ 3. SLR reduced by $2 \%$} \\
\hline Bank & +0.56 & -3.10 & 0.88 & +0.40 & -10.05 & 0.24 \\
\hline OFIs & -35.77 & -76.29 & 0.59 & -40.92 & +83.49 & 1.16 \\
\hline PCB (-) & -12.18 & -29.25 & 0.46 & -13.68 & +17.77 & 1.66 \\
\hline Household (-) & -7.59 & -17.46 & 0.50 & -9.16 & +14.56 & 1.37 \\
\hline \multicolumn{7}{|c|}{ 4. Deposit rate increased by $2 \%$} \\
\hline Bank & +0.48 & +1.69 & 0.84 & +0.19 & +5.14 & 0.25 \\
\hline OFIs & +26.83 & +38.44 & 0.61 & +19.62 & -39.66 & 1.24 \\
\hline PCB (-) & +10.16 & +15.18 & 0.45 & +7.23 & -7.79 & 1.92 \\
\hline Household (-) & +5.78 & +8.55 & 0.54 & +4.22 & -7.07 & 1.43 \\
\hline \multicolumn{7}{|c|}{ 5. Gov. Debt Yds reduced by $2 \%$} \\
\hline Bank & +1.04 & +1.50 & 0.55 & & & \\
\hline OFIs & +28.88 & +23.87 & 0.57 & & & \\
\hline PCB (-) & +9.85 & +8.50 & 0.47 & & & \\
\hline Household (-) & +7.70 & +6.58 & 0.40 & & & \\
\hline \multicolumn{7}{|c|}{ 6. OMO purchases $2 \%$} \\
\hline Bank & & & & +1.02 & +1.30 & 0.56 \\
\hline OFIs & & & & +21.77 & -4.61 & 5.38 \\
\hline PCB (-) & & & & +6.68 & -1.87 & 3.97 \\
\hline Household (-) & & & & +6.70 & +0.77 & 6.63 \\
\hline
\end{tabular}

$\%$ change in loan outstanding as an asset for banks and OFIs, and as a liability (-) for PCBs and households.

$\mathrm{D}=$ Deterministic simulation, $\mathrm{S}=$ Stochastic simulation

$\mathrm{RSE}=$ Relative Standard Error defined as SE/mean, where SE $=\mathrm{SD} / \sqrt{500}$ and SD $=$ Standard Deviation of the stochastic simulation 


\section{Footnotes}

1 There is a considerable time lag in the flow data published in the Reserve Bank of India Bulletin. The latest detailed flow data are those for 1993/94 published in 1998.

2 The CRR varied between $3 \%$ and $15 \%$ of total deposit liabilities over the period 1951-94. The SLR was set at $20 \%$ of total deposit liabilities until 1963; since then it has been varied within a range of $20 \%$ to $38.5 \%$.

3 We exclude the foreign sector as India was subject to strict foreign exchange controls for almost all the estimation period.

4 Bank rate is the central bank's rediscount rate, and is the borrowing rate for banks at the Reserve Bank of India.

5 Although lending rates were regulated for most of the sample period, banks could carry out some lending to the corporate sector at unregulated rates.

6 The financial year starts on the $1^{\text {st }}$ April and ends on the $31^{\text {st }}$ March in India.

7 The rate of change in share prices is used since dividend yield data are not available for the full sample period.

8 Due to space constraints, the results of the behavioural equations (.) marked in Table 1 are not reported here, but are available from the authors on request.

9 Consistent specification of the covariances is potentially a very complex task (Smith, 1981). However, we do enforce the homogeneity and symmetry restrictions throughout, and this necessarily imposes a meaningful covariance structure on the simulations.

10 Nominal interest rates were changed but, since product prices are exogenous in the model, this also amounts to a change in real interest rates.

11 The effective tax rate is approximately equal to the reserve ratio, depending in part on how banks would have allocated their funds in the absence of reserve ratios. Artis et. al. (1978) explain this point and discuss the tax and wealth effects of reserve ratios.

12 Note that the high relative standard error in the bank rate simulation in R1 is mainly an artefact due to the very small mean effect, and is not therefore a source of concern 